\title{
Distribution of polycyclic aromatic hydrocarbons in subcellular root tissues of ryegrass (Lolium multiflorum Lam.)
}

\author{
Fuxing Kang, Dongsheng Chen, Yanzheng Gao*, Yi Zhang
}

\begin{abstract}
Background: Because of the increasing quantity and high toxicity to humans of polycyclic aromatic hydrocarbons (PAHs) in the environment, several bioremediation mechanisms and protocols have been investigated to restore PAH-contaminated sites. The transport of organic contaminants among plant cells via tissues and their partition in roots, stalks, and leaves resulting from transpiration and lipid content have been extensively investigated. However, information about PAH distributions in intracellular tissues is lacking, thus limiting the further development of a mechanism-based phytoremediation strategy to improve treatment efficiency.

Results: Pyrene exhibited higher uptake and was more recalcitrant to metabolism in ryegrass roots than was phenanthrene. The kinetic processes of uptake from ryegrass culture medium revealed that these two PAHs were first adsorbed onto root cell walls, and they then penetrated cell membranes and were distributed in intracellular organelle fractions. At the beginning of uptake $(<50 \mathrm{~h})$, adsorption to cell walls dominated the subcellular partitioning of the PAHs. After $96 \mathrm{~h}$ of uptake, the subcellular partition of PAHs approached a stable state in the plant water system, with the proportion of PAH distributed in subcellular fractions being controlled by the lipid contents of each component. Phenanthrene and pyrene primarily accumulated in plant root cell walls and organelles, with about $45 \%$ of PAHs in each of these two fractions, and the remainder was retained in the dissolved fraction of the cells. Because of its higher lipophilicity, pyrene displayed greater accumulation factors in subcellular walls and organelle fractions than did phenanthrene.

Conclusions: Transpiration and the lipid content of root cell fractions are the main drivers of the subcellular partition of PAHs in roots. Initially, PAHs adsorb to plant cell walls, and they then gradually diffuse into subcellular fractions of tissues. The lipid content of intracellular components determines the accumulation of lipophilic compounds, and the diffusion rate is related to the concentration gradient established between cell walls and cell organelles. Our results offer insights into the transport mechanisms of PAHs in ryegrass roots and their diffusion in root cells.
\end{abstract}

\section{Background}

Polycyclic aromatic hydrocarbons (PAHs) are a group of persistent organic contaminants (POPs) that are ubiquitous in the environment [1-3]. Their toxicity (e.g., mutagenic, carcinogenic) and potential of accumulation in biota have led to concern about their fate and transport in the environment [4-6]. The major sources of PAHs in the environment include incomplete combustion of

\footnotetext{
* Correspondence: gaoyanzheng@njau.edu.cn

Institute of Organic Contaminant Control and Soil Remediation, College of Resource and Environment Science, Nanjing Agricultural University, Nanjing
} 210095, China

() 2010 Kang et al; licensee BioMed Central Ltd. This is an Open Access article distributed under the terms of the Creative Commons Attribution License (http://creativecommons.org/licenses/by/2.0), which permits unrestricted use, distribution, and reproduction in any medium, provided the original work is properly cited. organic residues (polymerization of benzene rings at high temperature), petroleum production, volcanic eruptions, and enzymatic polymerization of the benzene ring from plant exudates to the soil $[7,8]$. Although these contaminants are mainly metabolized and decomposed via environmental biotic and abiotic processes $[9,10]$, PAHs in the environment have gradually increased over the past several decades. For example, in Daya Bay, South China, before 1955, the temporal distribution of PAH concentrations in sediments was below $150 \mu \mathrm{g} \cdot \mathrm{kg}^{-1}$ (dry weight), but by 1995 , concentrations had risen to $300 \mu \mathrm{g} \cdot \mathrm{kg}^{-1}$ [11]. This increased PAH accumulation in 
the environment is because the rate of PAH release from anthropogenic activities is greater than the rate of natural attenuation.

Several remediation technologies and protocols have been developed to restore PAH-contaminated sites [7]. Phytoremediation is a potent and efficient approach that removes PAHs from contaminated sites into plants and decomposes them to less hazardous or non-hazardous forms with minimum input of chemicals and energy [7,12-15]. Previous studies have shown the efficacy of plant uptake and metabolism of PAHs in removing PAHs from the environment [16-18]. In general, two primary processes are responsible for PAH transfer and distribution in plant tissues: (1) transfer between plant tissues and cells driven by transpiration and the PAH concentration gradient across plant-cell components and (2) accumulation of PAHs in plant tissues, with the extent related to plant lipid contents [18-21]. However, the factors that influence PAH transfer and distribution in plants as well as their metabolism in cells are not clear. Plant uptake of PAHs from contaminated media is primarily through the roots and secondarily through leaves [16-18]. PAHs and their degradation products have frequently been detected within plant tissues [13]. A recent study has shown that in Zea mays phenanthrene can be metabolized into more polar products [22]. In another study, anthracene and formed metabolites were bound to several cell-wall components, such as pectin, lignin, hemicellulose, and cellulose [23]. Similarly, Wild et al. (2005) investigated the distributions of anthracene and its metabolites in Zea mays and suggested that the metabolism of anthracene occurs predominantly in the cell wall [24].

Uptake from water and soil via plant roots is a major pathway of PAH entry into plants. Wild et al. (2005) reported that PAHs first adsorbed to root surfaces and then passed through the membranes of adjoining cells before accumulating in cell walls and vacuoles [24]. The amount of uptake depended primarily on the lipid content of plant roots, in which protein, fats, nucleic acids, cellulose tissues, and other components all contain lipophilic components, which appear to be the primary domains where PAHs accumulate once they penetrate plant root cells [18]. Unfortunately, despite extensive studies on the transport of organic contaminants (especially PAHs) in plants, information about PAH distributions in intracellular tissues of plant roots, stalks, and leaves is lacking. This limits the development of mechanism-based phytoremediation strategies to better improve treatment efficiency.

In this study, we investigated the uptake and subcellular distributions of PAHs in root cells of ryegrass (Lolium multiflorum Lam.), which is widely used in the phytoremediation of $\mathrm{PAH}$-contaminated sites owing to its fibrous root system and large specific root surface area. Our results will enhance the understanding of $\mathrm{PAH}$ transfer mechanisms in plants and their effects on the distribution of PAHs in plants.

\section{Results and Discussion}

\section{Uptake of phenanthrene and pyrene by roots}

In Figure 1, the uptake of phenanthrene and pyrene from Hoagland medium by ryegrass roots is shown as a function of exposure time. The uptake rate and magnitude of uptake of phenanthrene and pyrene by ryegrass roots differed. Concentrations of phenanthrene and pyrene in roots increased with exposure time, reaching a maximum at $\sim 100 \mathrm{~h}$. Although phenanthrene concentrations in roots were higher within this timeframe, they were less than two times the concentration of pyrene, most likely because of a higher initial concentration in the medium of phenanthrene $\left(2.5 \mathrm{mg} \cdot \mathrm{L}^{-1}\right)$ than of pyrene $\left(0.5 \mathrm{mg} \cdot \mathrm{L}^{-1}\right)$. From 100 to $240 \mathrm{~h}$, the phenanthrene concentration in roots decreased sharply from 90 to 18 $\mathrm{mg} \cdot \mathrm{kg}^{-1}$, whereas that of pyrene declined gradually from 60 to $48 \mathrm{mg} \cdot \mathrm{kg}^{-1}$. These differing uptake patterns could result from a difference in the migration of phenanthrene and pyrene to ryegrass shoots, their degradation in roots, or both. The slower rate of pyrene reduction after $100 \mathrm{~h}$ indicates that pyrene is recalcitrant to metabolism in roots and that, as the more lipophilic compound, it exhibits a strong affinity for plant tissues, slowing its transport from roots to shoots.

Although spontaneous volatilization could be a cause of PAH dissipation from water, it is thought to be primarily related to plant accumulation and metabolism [2]. Figure 2 shows the dissipation efficiency of PAHs from Hoagland solution by ryegrass, which we defined

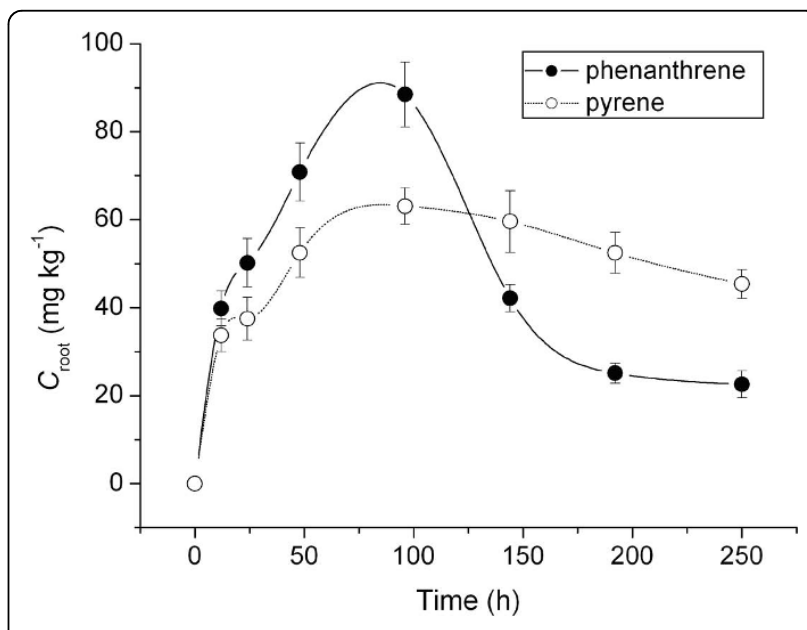

Figure 1 Concentrations of phenanthrene and pyrene in ryegrass roots as a function of uptake time. $C_{\text {root }}$ means concentrations of phenanthrene and pyrene in ryegrass root. 


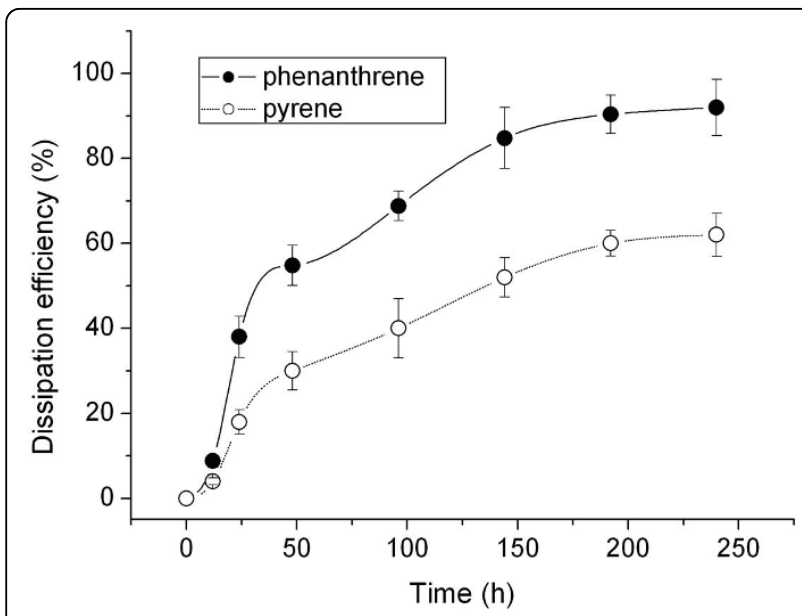

Figure 2 Dissipation efficiency (\%) of phenanthrene and pyrene by ryegrass from aqueous solution as a function of exposure time. The values were defined as ratio of PAH removal to the initial concentration from the aqueous solution. It explained in principle the plant-affected dissipation of phenanthrene and pyrene from solution, and such dissipation was primarily related to plant accumulation and metabolism.

as the ratio of PAH removal to the initial concentration of PAH in aqueous solution. Dissipation efficiency increased gradually with exposure time, reaching $92 \%$ for phenanthrene and $62 \%$ for pyrene at 250 hours. This result is consistent with the relatively rapid reduction of phenanthrene in ryegrass roots, which could be due to its high metabolism rate in ryegrass, relatively quick migration from roots to shoots, or both.

The root concentration factor (RCF) describes the capability of roots to accumulate contaminants from direct contact with an aqueous environment, which is here defined as the ratio of $\mathrm{PAH}$ concentration in roots $\left(C_{\text {root }}\right)$ to that in the culture medium $\left(C_{\text {solution }}\right): \operatorname{RCF}=$ $C_{\text {root }} / C_{\text {solution }}$ [25-27]. RCF values increased with increasing root/solution contact time before approaching a nearly constant value after $150 \mathrm{~h}$ (Figure 3 ). The RCF values of pyrene were about two times greater than those of phenanthrene. Our previous study indicated that the lipophilicity (e.g., $\log K_{\text {ow }}$ ) of a compound is a determinant of the magnitude of plant uptake [18]. The higher pyrene RCF is due to its greater lipophilicity (log $\left.K_{\mathrm{ow}}=5.32\right)$ compared with that of phenanthrene (log $\left.K_{\text {ow }}=4.46\right)$. Gao et al. (2004) reported that pyrene uptake by plants from soil was 4-7 times greater than uptake of phenanthrene [18]. Together, these results suggest that more lipophilic organic contaminants have a higher propensity for uptake in plants via roots.

\section{Subcellular movement and distribution of phenanthrene and pyrene in root cells}

Figure 4 shows phenanthrene and pyrene concentrations in root subcellular fractions. Phenanthrene concentrations

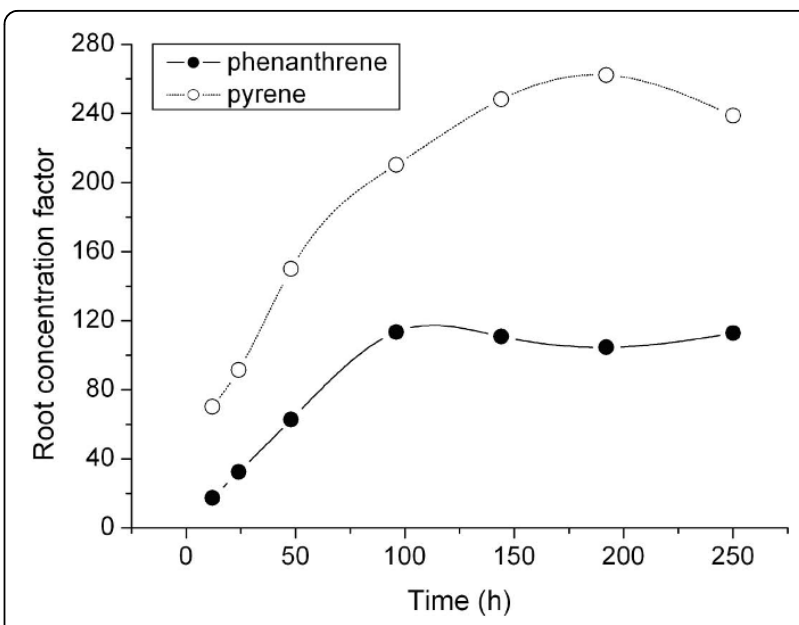

Figure 3 Root concentration factor (RCF) of phenanthrene and pyrene for ryegrass uptake from aqueous solution. Root concentration factor (RCF) describes the capability of roots to accumulate contaminants from the direct contact with the aqueous environment, which is here defined as the ratio of PAH

concentration in root $\left(C_{\text {root }}\right)$ to that in culture medium $\left(C_{\text {solution }}\right)$, i.e., $\mathrm{RCF}=\mathrm{C}_{\text {root }} / \mathrm{C}_{\text {solution }}$.

in cell walls and organelles increased gradually to 79 and $95 \mathrm{mg} \cdot \mathrm{kg}^{-1}$, respectively, and then decreased to 16.5 and $17 \mathrm{mg} \cdot \mathrm{kg}^{-1}$ as exposure time lengthened (Figure 4a). Pyrene underwent a similar uptake pattern: pyrene concentrations in cell walls and organelles rose to 58 and $71 \mathrm{mg} \cdot \mathrm{kg}^{-1}$, respectively, and then decreased to 38 and $56 \mathrm{mg} \cdot \mathrm{kg}^{-1}$ (Figure $4 \mathrm{~b}$ ). Before $70 \mathrm{~h}$ of uptake, concentrations of both PAHs in cell walls were greater than those in organelles. Moreover, the uptake by organelle components was slower in reaching a maximum relative to cell walls. The two PAHs first adsorbed onto cell walls from the culture medium, and they then diffused into cell organelle components. After $70 \mathrm{~h}$, a relatively higher concentration of both PAHs was found in the organelle fraction than in cell walls due to the greater accumulation of lipophilic compounds in the fraction containing a higher lipid content, i.e., organelle components. After $96 \mathrm{~h}$ of exposure, phenanthrene uptake rapidly decreased in root cell walls and organelles, whereas the decrease in pyrene was much slower in these two subcellular fractions. This trend is consistent with the uptake patterns of the two contaminants by ryegrass roots shown in Figure 1.

PAHs in roots were distributed into three subcellular fractions: water-soluble, cell wall, and organelle. The proportions of phenanthrene and pyrene in the watersoluble, wall, and organelle fractions are plotted against exposure time in Figure 5. From $12 \mathrm{~h}$ to $240 \mathrm{~h}$ of exposure, the percentage of phenanthrene in cell walls notably descended from $84 \%$ to $42 \%$ and pyrene decreased from $60 \%$ to $41 \%$. Within the same period, 

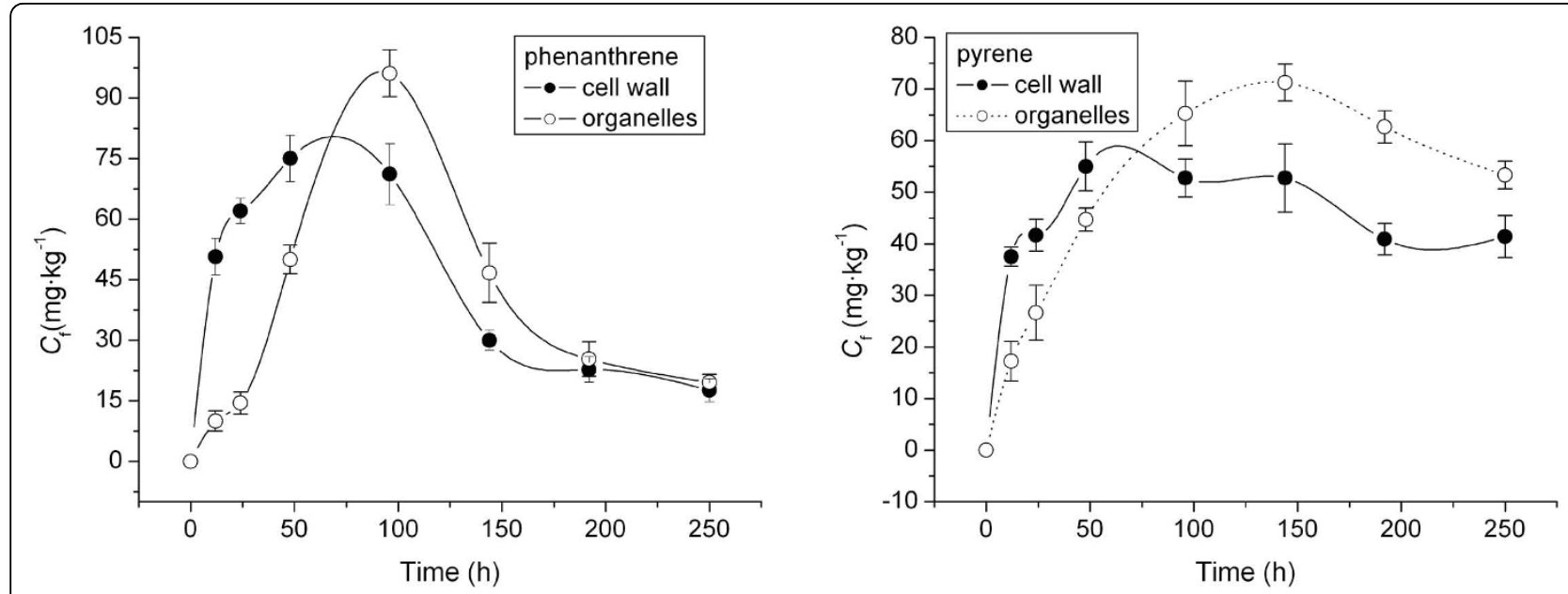

Figure 4 Concentrations of phenanthrene (a) and pyrene (b) in root cell walls and organelles as a function of time. $C_{f}$ means concentrations of phenanthrene and pyrene in root subcellular fractions.

phenanthrene and pyrene distributions in organelles increased from $8.5 \%$ to $41 \%$ and from $21 \%$ to $33 \%$, respectively. Both PAHs showed a relatively small variation in the proportion in the aqueous soluble fraction, $\sim 10-15 \%$ for phenanthrene and $\sim 10-20 \%$ for pyrene. Thus, at the beginning of uptake (i.e., $<96 \mathrm{~h}$ ), the decrease of PAH in cell walls largely corresponded to the increase in cell organelles, suggesting that PAHs first accumulated in cell walls via direct contact with Hoagland solution and then gradually transferred to fractions inside cells, such as organelles. After $96 \mathrm{~h}$ of exposure, the distributions of both PAHs in cell components approached a relatively stable state in cell walls and organelles (Figure 5). In ryegrass root cells, content in cell walls was $8.9 \%$, and that in organelles was $6.0 \%$. The relatively smaller organelle fraction accumulated a similar amount of each PAH compared with that in cell walls, likely owing to the higher lipid content of organelles. Generally, the uptake capability of root tissues for organic lipophilic compounds increases with $K_{\mathrm{ow}}$ value (i.e., $K_{\text {ow }}>\sim 10^{4}$ ), with more lipophilic compounds showing a higher accumulation in plants, particularly in plant tissues containing a high lipid content $[20,21,28,29]$. Lipids in plant cell walls are composed mostly of polysaccharides (90\%), with a few structural proteins, lignin, lectin, and mineral elements as well as a very small lipid component. In contrast, the lipid content of plant organelles is $15-30 \%$ [30], enabling them to draw PAHs from the cell wall. Thus, the relatively higher lipid content of the organelle fraction is believed to be responsible for the greater accumulation of PAHs, and the corresponding concentration gradient
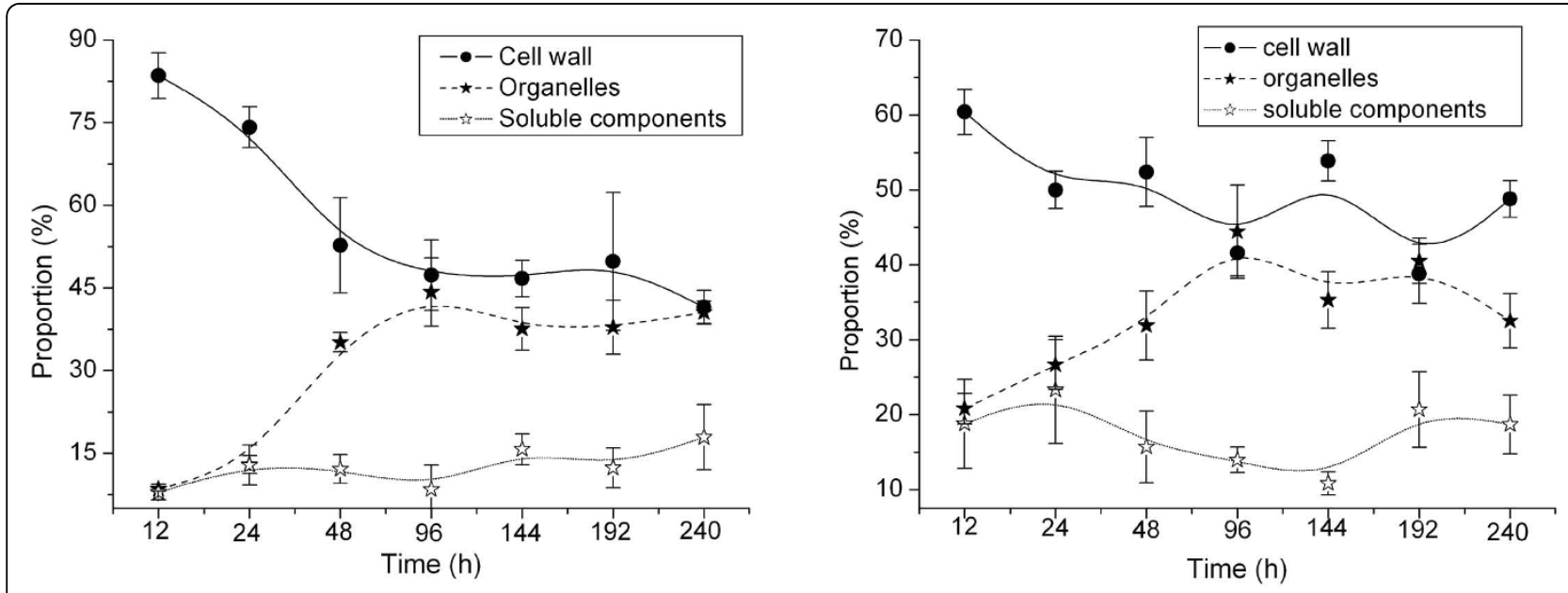

Figure 5 Proportions of phenanthrene (a) and pyrene (b) distributed in cell water soluble fraction, wall and organelle as a function of uptake time. The proportion of PAHs was calculated from the measurement of PAH in each fraction to the total amount in ryegrass root cells. 
established between organelles and cell walls in the beginning stage of uptake $(<96 \mathrm{~h})$ is the driving force for the diffusion of PAHs to interior cell components.

As shown in Figure 5, PAH concentrations in soluble components stayed nearly constant. The separated soluble cellular components, mainly consisting of cell solution and largely concentrated in the cell matrix between cells or organelles, can be regarded as an intracellular buffering distribution phase. Due to the hydrophobicity of PAHs, these aqueous substances were not easily enriched. Thus, the non-affinity between PAHs and soluble cellular components may result in distributive constant and low partitioning proportions.

Subcellular fraction-concentration factor (SFCF) values, defined as the ratio of $\mathrm{PAH}$ concentration in subcellular fractions to that in water-soluble cellular components, are shown in Figure 6. The SFCF of phenanthrene in cell walls decreased from 101 to $20 \mathrm{~L} \cdot \mathrm{kg}^{-1}$ over $240 \mathrm{~h}$ of exposure. For pyrene, the SFCF in cell walls first increased from 16 to $48 \mathrm{~L} \cdot \mathrm{kg}^{-1}$ and then decreased rapidly to $<25 \mathrm{~L} \cdot \mathrm{kg}^{-1}$. The difference in cellwall SFCFs of phenanthrene and pyrene likely resulted from the different properties of the two PAHs, as in the beginning stage, pyrene tended to accumulate more in cell walls than in water-soluble components owing to its higher $\log K_{\mathrm{ow}}$.

In the initial $48 \mathrm{~h}$, the SFCFs of the two PAHs were greater in cell walls than in cell organelles. After that period, organelle fraction SFCFs slightly exceeded those of cell walls. These results suggest that within the first $48 \mathrm{~h}$ of exposure, subcellular transport of PAHs occurred from cell walls to intracellular organelles as a result of the concentration gradient.

\section{Conclusions}

Transpiration is generally considered to be the main transfer mechanism of PAHs in plants, such as from roots to stalks and leaves [9]. PAHs initially adsorb to plant cell walls and then gradually diffuse into subcellular tissues. The lipid contents of intracellular components determine the extent of lipophilic compound accumulation, and the diffusion rate is related to the concentration gradient established between cell walls and organelles inside cells. In addition, although both phenanthrene and pyrene are grouped among organic compounds that share similar properties, pyrene displays greater accumulation factors in subcellular walls and organelle fractions due to a higher $\log K_{\mathrm{ow}}$. Our results will be useful in evaluating human exposure risks of PAH-contaminated crops and in developing appropriate strategies for the phytoremediation of PAH-contaminated sites.

\section{Remaining question}

To our best knowledge, this is the first paper reporting the distribution of persistent organic pollutants (POPs), with PAHs as representatives, in plant subcellular tissues. It is noteworthy that in this study, although the negligible amounts of pure cell membrane could not be separated from other cell fractions by the centrifugal method and it was merged into the soluble components in the investigation, results of this work open new insights into POP subcellular transport and distribution in plants.

\section{Methods}

\section{Chemicals}

Phenanthrene and pyrene (> 98\% purity) were purchased from Sigma-Aldrich GmbH (Munich, Germany). Table 1 lists some physicochemical properties of the
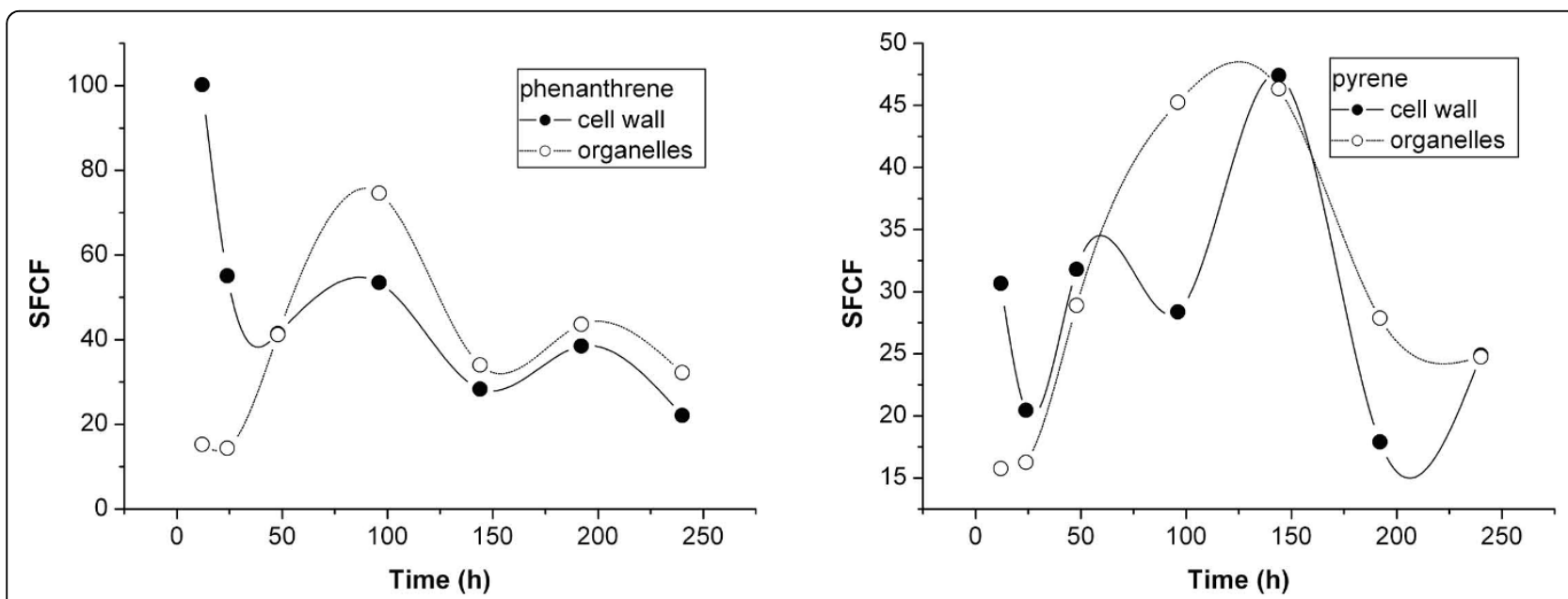

Figure 6 Subcellular fraction concentration factors (SFCF) of phenanthrene (a) and pyrene (b) for ryegrass root uptake as a function of time $\mathbf{0} \mathbf{2 4 0} \mathbf{h}$. SFCF was defined as the ratio of PAH concentration in subcellular fractions including cell wall and organelle to that in cell water-soluble components. 
Table 1 Some physicochemical properties of phenanthrene and pyrene

\begin{tabular}{lccc}
\hline PAHs & $\begin{array}{c}\text { Molar weight } \\
\left(\mathbf{g} \cdot \mathbf{m o l}^{-1}\right)\end{array}$ & $\begin{array}{c}\text { Water solubility }\left(\mathbf{m g} \cdot \mathbf{L}^{-1}\right. \\
\text { at } \mathbf{2 5}\end{array}$ & log $\mathbf{~} K_{\text {ow }}$ \\
\hline Phenanthrene & 178.23 & 1.18 & 4.46 \\
Pyrene & 202.26 & 0.12 & 5.32 \\
\hline
\end{tabular}

two PAHs. Milli-Q grade water (Millipore, Billerica, MA, USA; $18.2 \mathrm{M} \Omega \cdot \mathrm{cm}^{-1}$ resitivity) was used to prepare solutions. Hoagland solution was prepared in $1.0 \mathrm{~L}$ water as follows: $\mathrm{KNO}_{3}(607 \mathrm{mg}), \mathrm{Ca}\left(\mathrm{NO}_{3}\right)_{2}(945 \mathrm{mg}),\left(\mathrm{NH}_{4}\right)$ ${ }_{3} \mathrm{PO}_{3}(115 \mathrm{mg}), \mathrm{MgSO}_{4}(493 \mathrm{mg}), \mathrm{FeSO}_{4} \cdot 7 \mathrm{H}_{2} \mathrm{O}(13.9$ $\mathrm{mg})$, EDTA.2Na (18.65 mg), KI (0.00415 mg), $\mathrm{H}_{3} \mathrm{BO}_{3}$ (0.031 mg), $\mathrm{MnSO}_{4}(0.1115 \mathrm{mg}), \mathrm{ZnSO}_{4}(0.043 \mathrm{mg})$, $\mathrm{Na}_{2} \mathrm{MoO}_{4}(0.00125 \mathrm{mg}), \mathrm{CuSO}_{4}(0.000125 \mathrm{mg})$, and $\mathrm{CoCl}_{2}(0.000125 \mathrm{mg})$.

\section{Plant uptake experiment}

Ryegrass root uptake of phenanthrene and pyrene from aqueous Hoagland solution was investigated using batch settings. A stock methanol solution of phenanthrene and pyrene was added to aqueous Hoagland solution according to the method described by Chapin et al. [31]. The methanol concentration in the Hoagland solution was less than $0.1 \%$ (vol/vol). Following germination in vermiculite, seedlings were transferred to a tray containing Hoagland solution and grown in a greenhouse at $25-30^{\circ} \mathrm{C}$ in daytime and $20-25^{\circ} \mathrm{C}$ at night. After about 2 weeks of growth, the plants were approximately $10 \mathrm{~cm}$ tall with relatively mature roots, and they were used for uptake experiments.

The seedlings were then transplanted to Hoagland culture solutions containing phenanthrene and pyrene. Twelve seedlings were cultured in each glass beaker, with roots submerged in the culture medium. Four replicates of each treatment were conducted. During the experimental period, the seedlings were incubated at 25$30^{\circ} \mathrm{C}$ during daytime and $20-25^{\circ} \mathrm{C}$ at night. The culture beakers were wrapped with black cloth to reduce the impact of potential photolysis. Each day, PAH-free control Hoagland solution was added to both the experimental and PAH-free control beakers to maintain the same initial volume of each treatment. At 12-, 24-, 48-, 96-, 168-, and 240-h exposure, the Hoagland solution and corresponding seedlings were sampled and prepared for PAH analysis. Seedling roots were washed several times using Milli-Q water and then separated into cellwall and organelle fractions to measure PAH distributions at the subcellular level (see below).

\section{Subcellular fraction}

A modification of the methods of Lai et al. (2006), Li et al. (2006), and Wei et al. (2005) was used to obtain subcellular fractions of root cells [32-34]. Briefly, fresh roots were mixed with extraction buffer containing 50 mM HEPES, $500 \mathrm{mM}$ sucrose, $1.0 \mathrm{mM}$ DTT, $5.0 \mathrm{mM}$ ascorbic acid, and $1.0 \%(\mathrm{w} / \mathrm{v})$ polyclar AT PVPP. The buffer solution $\mathrm{pH}$ was adjusted to 7.5 using $1.0 \mathrm{M}$ $\mathrm{NaOH}$. The root tissue extract was ground, passed through a $60-\mu \mathrm{m}$ sieve, and subsequently centrifuged at $500 \mathrm{~g}$ for $5 \mathrm{~min}$ to obtain a pellet of cell debris. This pellet was referred to as the wall fraction of the root cells. The supernatant was then centrifuged at 10,000 g for $30 \mathrm{~min}$ to obtain the cell organelle fraction. All extraction steps were performed at $4^{\circ} \mathrm{C}$. The dried cellwall and organelle powders were placed in a vacuum freeze drier (Labconco, Kansas City, MO, USA) at $-65^{\circ}$ C. Fraction contents, determined gravimetrically, were $6.0 \%$ organelles and $8.9 \%$ cell walls, with the remainder being water and water-soluble fractions.

\section{Analysis of PAHs}

PAHs were extracted from cell fractions using ultrasonication [18]. In brief, the cell fractions (cell walls and organelles) were freeze-dried and then extracted for $1 \mathrm{~h}$, using an acetone and hexane mixture ( $\mathrm{vol} / \mathrm{vol}=1: 1$ ), followed by $1 \mathrm{~h}$ of ultrasonic extraction. This acetone/ hexane extraction step was repeated three times, and the collected extracts were combined. The solvents were then evaporated using a rotary evaporator and exchanged to $2 \mathrm{~mL}$ hexane, followed by a clean-up procedure through a $2-\mathrm{g}$ silica gel column using an $11-\mathrm{mL}$ $1: 1(\mathrm{v} / \mathrm{v})$ elution of hexane and dichloromethane. The samples were then evaporated and exchanged to methanol, with a final volume of $2 \mathrm{~mL}$. Phenanthrene and pyrene were analyzed using high-performance liquid chromatograph (LC-20AT; Shimadzu, Kyoto, Japan) equipped with a UV detector and a $\Phi 4.6 \times 150-\mathrm{mm}$ reverse phase $C_{18}$ column. The UV-detector wavelength was set at $254 \mathrm{~nm}$. The mobile phase was spectrumpure methanol with a flow rate at $1.0 \mathrm{~mL} \cdot \mathrm{min}^{-1}$, and the column temperature was $30^{\circ} \mathrm{C}$.

\section{Statistical Analysis}

All data were calculated using Origin version 7.0. Every data point in the Figures is an average value. The standard deviation (SD), obtained from four parallel samples using the Origin software, is shown in the Figures as an error bar. Data were analyzed using analysis of variance (ANOVA). The statistical package used was SPSS (Version 11.0), and the confidence limit was $95 \%$.

\section{Acknowledgements}

We gratefully thank the Dr Hui Li in Michigan State University for his assistance with paper revision. The work was supported by the National Natural Science Foundation of China (20777036, 21077056, 41071212, 40701073, 40971137), the Natural Science Foundation of Jiangsu Province 
(BK2009315), the Fok Ying Tung Education Foundation (122045), and the Foundation of the State Key Laboratory of Soil and Sustainable Agriculture, China (Y052010021).

\section{Authors' contributions}

YZG performed the project planning. DSC performed the experimental work, while FXK, DSC, YZG, and YZ performed the data analysis. FXK, DSC, and YZG wrote the manuscript. All authors read and approved the final manuscript for submission.

Received: 13 April 2010 Accepted: 22 September 2010

Published: 22 September 2010

\section{References}

1. Sung KJ, Munster CL, Rhykerd R, Drew MC, Corapcioglu MY: The use of box lysimeters with freshly contaminated soils to study the phytoremediation of recalcitrant organic contaminants. Environmental Science and Technology 2002, 36:2249-2255.

2. Gao YZ, Ling WT, Wong MH: Plant-accelerated dissipation of phenanthrene and pyrene from water in the presence of a nonionicsurfactant. Chemosphere 2006, 63:1560-1567.

3. Gao YZ, Ling WT, Zhu LZ, Zhao BW, Zheng QS: Surfactant-enhanced phytoremediation of soils contaminated with hydrophobic organic contaminants: potential and assessment. Pedoshpere 2007, 17(4):409-418.

4. Kästner M, Breuer-Jammali M, Mahro B: Impact of inoculation protocols, salinity, and $\mathrm{pH}$ on the degradation of polycyclic aromatic hydrocarbons (PAHs) and survival of PAH-degrading bacteria introduced into soil. Applied and Environmental Microbiology 1998, 64:359-362.

5. Hamdi H, Benzarti S, Manusadžianas L, Aoyama I, Jedidi N: Bioaugmentation and biostimulation effects on PAH dissipation and soil ecotoxicity under controlled conditions. Soil Biology and Biochemistry 2007, 39:1926-1935.

6. Aufman J, Khalil F: Carcinogenesis of lung cancer, Mechanisms of Oncogenesis. Cancer Growth and Progression 2010, 12:203-212.

7. Haritash AK, Kaushik CP: Biodegradation aspects of Polycyclic Aromatic Hydrocarbons (PAHs): A review. Journal of Hazardous Materials 2009, 169:1-15.

8. Dong TT, Lee BK: Characteristics, toxicity, and source apportionment of polycylic aromatic hydrocarbons (PAHs) in road dust of Ulsan, Korea. Chemosphere 2009, 74:1245-1253.

9. Wang XR: Environmental chemistry. Nanjing University Press, first 1993.

10. Cavalca L, Rao MA, Bernasconi S, Colombo M, Andreoni V, Gianfreda L: Biodegradation of phenanthrene and analysis of degrading cultures in the presence of a model organo-mineral matrix and of a simulated NAPL phase. Biodegradation 2008, 19:1-13.

11. Yan W, Chi J, Wang ZY, Huang WX, Zhang G: Spatial and temporal distribution of polycyclic aromatic hydrocarbons (PAHs) in sediments from Daya Bay, South China. Environmental Pollution 2009, 157:1823-1830.

12. Providenti MA, Lee $H$, Trevors JT: Selected factors limiting the microbial degradation of recalcitrant compounds. Journal of Industrial Microbiology 1993, 12:379-395.

13. Ward OP, Singh A, Van Hamme J: Acclerated biodegradation of petroleum hydrocarbon waste. Journal of Industrial Microbiology \& Biotechnology 2003, 30:260-270.

14. Gan S, Lau EV, Ng HK: Remediation of soils contaminated with polycyclic aromatic hydrocarbons (PAHs). Journal of Hazardous Materials 2009, 172:532-549.

15. Wei SQ, Pan SW: Phytoremediation for soils contaminated by phenanthrene and pyrene with multiple plant species. $J$ of Soils and Sediments 2010, 10:886-894

16. Simonich $S L$, Hites RA: Vegetation atmosphere partitioning of polycyclic aromatic hydrocarbons. Environmental Science and Technology 1994, 28:939-943.

17. Bakker MI, Vorenhout M, Sum D, Kollöffel CD: Dry deposition of atmospheric polycyclic aromatic hydrocarbons in three Plantago species. Environmental Toxicology and Chemistry 1999, 18:2289-2294.

18. Gao YZ, Zhu LZ: Plant uptake, accumulation and translocation of phenanthrene and pyrene in soils. Chemosphere 2004, 55:1169-1178.

19. Gao YZ, Collins CD: Uptake pathways of polycyclic aromatic hydrocarbons in white clover. Environmental Science and Technology 2009, 43:6190-6195.
20. Paterson S, Mackay D: A model of organic chemical uptake by plants from soil and the atmosphere. Environmental Science and Technology 1994, 28:2259-2265.

21. Wang $M$, Jones $\mathrm{KC}$ : Uptake of chlorobenzenes by carrots from spiked and sewage sludge-amended soil. Environmental Science and Technology 1994, 28:1260-1267.

22. Wild E, Dent J, Thomas GO, Jones KC: Visualizing the air-to-leaf transfer and within-leaf movement and distribution of phenanthrene: further studies utilizing two-photon excitation microscopy. Environmental Science and Technology 2006, 40:907-916.

23. Harms $\mathrm{HH}$ : Bioaccumulation and metabolic fate of sewage derived organic xenobiotics in plants. The Science of the Total Environment 1996, 185:83-92.

24. Wild E, Dent J, Thomas J, Jones K: Direct observation of organic contaminant uptake, storage, and metabolism within plant roots. Environmental Science and Technology 2005, 39:3695-3702.

25. Briggs GG, Bromilow RH, Evans AA: The relationships between lipophilicity and root uptake and translocation of non-ionised chemicals by barley. Pesticide Science 1982, 13:459-504.

26. Briggs $\mathrm{GG}$, Bromilow RH, Evans AA, Willams M: Relationship between lipophilicity and the distribution of non-ionized chemicals in barley shoot following uptake by the root. Pesticide Science 1983, 14:492-500.

27. Polder MD, Hulzebos EM, Jager DT: Validation of models on uptake of organic chemicals by plant roots. Environmental Toxicology and Chemistry 1995, 14(9):1615-1623.

28. Trapp S, Matthies M, Scheunert I, Topp EM: Modeling the bioconcentration of organic chemicals in plants. Environmental Science and Technology 1990, 24:1246-1252.

29. Gao YZ, Zhu LZ, Ling WT: Application of the partition-limited model for plant uptake of organic chemicals from soil and water. The Science of the Total Environment 2005, 336:171-182.

30. Li HS: Plant physiology. High Education Press, Beijing, second 2006.

31. Chapin FS, Moilanen L, Kielland K: Preferential use of organic nitrogen for growth by a non-mycorrhizal article sedge. Nature 1993, 361:150-153.

32. Lai $Y$, Wang $Q$, Yang $L$, Huang B: Subcellular distribution of rare earth elements and characterization of their binding species in a newly discovered hyperaccumulator Pronephrium simplex. Talanta 2006, 70:26-31.

33. Li TQ, Yang XE, Yang JY, He ZL: Zn accumulation and subcellular distribution in the $\mathrm{Zn}$ hyperaccumulator Sedurn alfredii hance. Pedosphere 2006, 16(5):616-623.

34. Wei ZG, Hong FS, Yin M, Li HX, Hu F, Zhao GW, Wong JW: Subcellular and molecular localization of rare earth elements and structural characterization of yttrium bound chlorophyll a in naturally grown fern Dicranopteris dichotoma. Microchemical Journal 2005, 80:1-8.

doi:10.1186/1471-2229-10-210

Cite this article as: Kang et al:: Distribution of polycyclic aromatic hydrocarbons in subcellular root tissues of ryegrass (Lolium multiflorum Lam.). BMC Plant Biology 2010 10:210.

\section{Submit your next manuscript to BioMed Central and take full advantage of:}

- Convenient online submission

- Thorough peer review

- No space constraints or color figure charges

- Immediate publication on acceptance

- Inclusion in PubMed, CAS, Scopus and Google Scholar

- Research which is freely available for redistribution

Submit your manuscript at www.biomedcentral.com/submit
C Biomed Central 